Cássio Hildebrand Pires da Cunha

\title{
RECURSO ESPECIAL REPETITIVO
}

DissertaÇÃo DE MESTRAdo

OrIENTADOR: Professor TITUlar CÂNDIDO RANGEL DINAMARCO

UNIVERSIDADE DE SÃO PAULO

FACULDADE DE DIREITO

São PaUlo - SP

2020 
Cássio Hildebrand Pires da Cunha

\section{RECURSO ESPECIAL REPETITIVO}

Dissertação apresentada à banca examinadora do programa de pós-graduação stricto sensu da Faculdade de Direito da Universidade de São Paulo - Departamento de Direito Processual - sob a orientação do Professor Titular Cândido Rangel Dinamarco, como requisito para a obtenção do título de mestre.

UNIVERSIDADE DE SÃO PAULO

FACULDADE DE DIREITO

SÃo PaUlo - SP 
Hildebrand, Cássio

Recurso Especial Repetitivo ; Cássio Hildebrand ; orientador Cândido Rangel Dinamarco -- São Paulo, 2020.

129

Dissertação (Mestrado - Programa de Pós-Graduação em Direito Processual) - Faculdade de Direito, Universidade de São Paulo, 2020.

1. Recurso especial repetitivo. 2. Recursos especiais representativos da controvérsia. 3 . Precedentes vinculantes. I. Dinamarco, Cândido Rangel, orient. II. Titulo. 
HILDEBRAND, Cássio

Recurso Especial Repetitivo

Dissertação apresentada à Faculdade de Direito da Universidade de São Paulo sob orientação do Professor Titular Cândido Rangel Dinamarco.

Resultado:

Data:

Orientador

Prof. Titular Cândido Rangel Dinamarco

Prof. Dr. Instituição:

Julgamento: Assinatura:

Prof. Dr. Instituição:

Julgamento: Assinatura:

Prof. Dr. Instituição:

Julgamento: Assinatura: 


\section{RESUMO}

Cássio Hildebrand Pires da Cunha. Recurso Especial Repetitivo. 129 páginas. Mestrado Faculdade de Direito, Universidade de São Paulo, São Paulo, 2020.

O objetivo deste trabalho é analisar o recurso especial repetitivo sob a ótica do histórico da tentativa de uniformização da jurisprudência no Brasil até a introdução dos precedentes vinculantes. Focado especificamente no recurso especial representativo de controvérsia, esta dissertação pretende explorar também os procedimentos atinentes a este instituto, desde a escolha dos casos que servirão como causa-piloto até os efeitos do julgamento no âmbito do Superior Tribunal de Justiça, com a aplicação da tese firmada no Tribunal de Superposição para aplicação em todos os processos que discutem a mesma questão jurídica. O estudo também traz uma análise acerca da atividade do Superior Tribunal de Justiça e apresenta críticas e sugestões para o desenvolvimento desta valiosa ferramenta de uniformização de jurisprudência com aplicação de uma justiça mais célere.

Palavras-chave: processo civil; recurso especial repetitivo; precedentes. 


\begin{abstract}
Cássio Hildebrand Pires da Cunha. Recurso Especial Repetitivo. 129 páginas. Mestrado Faculdade de Direito, Universidade de São Paulo, São Paulo, 2020.

The aim of this work is to analyze the repetitive special appeal observing the history of the attemp to fullfil the uniformization of Brazilian jurisprudence until the introduction of the obligatory precedents, by the 2015 Civilian Procedural Code. The main focus is specifically on the repetitive special appeals that will represent a litigation thesis before the Superior Court of Justice. This work also intends to explore all the proceedings regarding the institute, from thce choice of the cases that will represent the repetitive dispute until the effects of the final decision of the Superior Court of Justice, including the application of this decision for all the cases that were suspend in order to wait for this definite conclusion of the Superior Court. The study also brings some analisys on the way that the Superior Court is working the new institute, in order to criticize some aspects, praise some others and present some suggestions aiming the development of this precious technique that has been added to the Brazilian judicial system in order to bring more cohesion to the country's jurisprudence and some more urgency on the proceedings.
\end{abstract}

Keywords: civil procedure; repetitive special appeal; precedents. 


\section{SUMÁRIO}

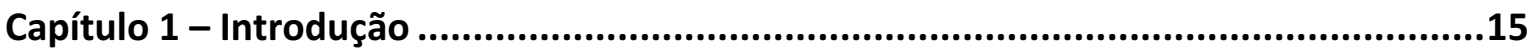

1.1. Justificativa para a criação do sistema de julgamentos por amostragem ................15

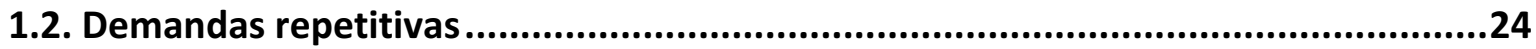

Capítulo 2 - Noções acerca do recurso especial e o surgimento da técnica de julgamento do recurso especial repetitivo .............................................................................31

2.1. Considerações iniciais sobre o recurso especial e a adoção da técnica do julgamento por amostragem ...........................................................................................

2.2. Importância, origem e regulamentação do julgamento dos recursos representativos

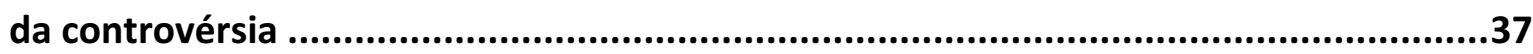

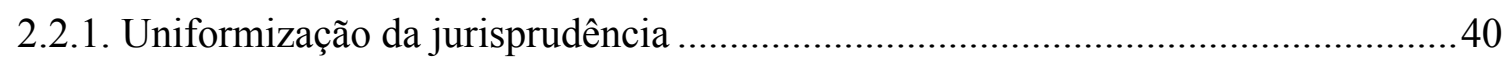

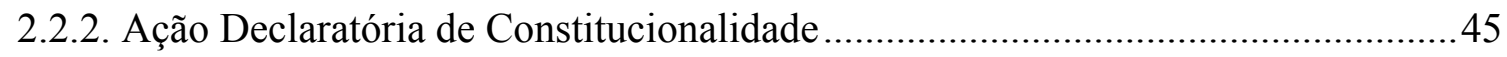

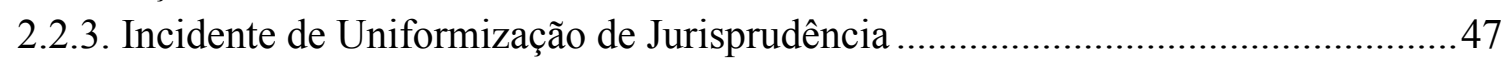

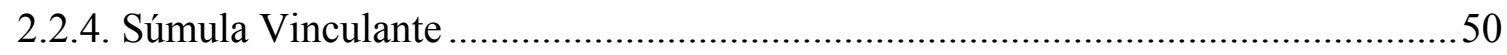

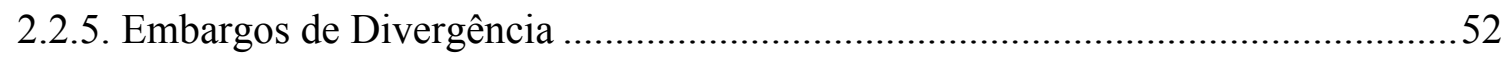

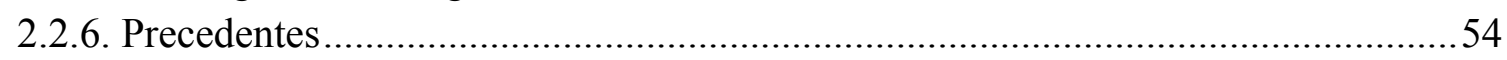

2.3. Função do recurso especial repetitivo ..........................................................57

2.4. Pilares norteadores do recurso especial repetitivo............................................62

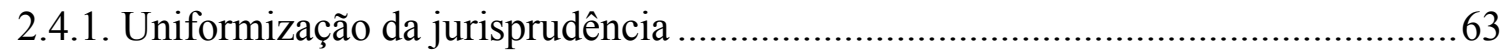

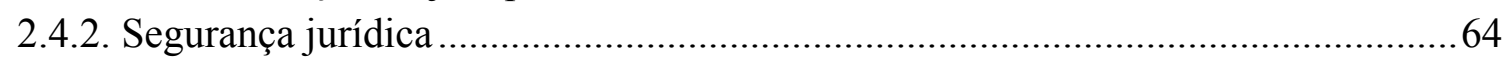

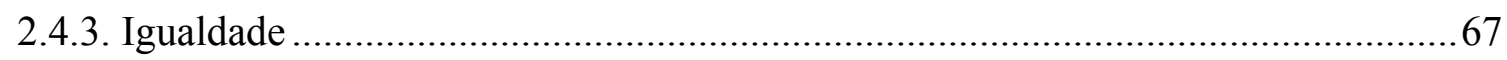

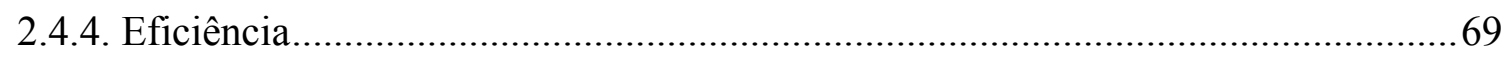

Capítulo 3 - Seleção dos recursos especiais representativos da controvérsia, afetação do tema e suspensão dos processos e recursos em trâmite ...............................................72

3.1. Afetação do tema e seleção dos recursos especiais representativos de controvérsia

3.2. Decisão de afetação do tema repetitivo...................................................................81

3.2.1. Fundamentação, publicidade e efeitos da decisão de suspensão dos recursos

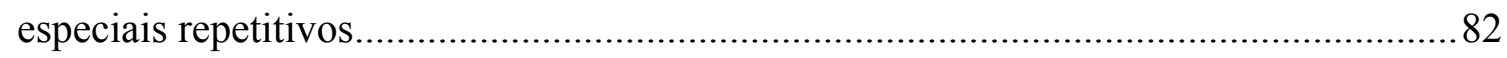

3.2.2. Meios de impugnação à suspensão dos processos supostamente repetitivos.......... 84

3.3. Suspensão parcial dos processos.........................................................................90

3.4. Prazo de suspensão e consequência de eventual descumprimento ........................91

3.5. Vinculação dos Juizados Especiais Cíveis ao rito de julgamentos dos recursos especiais repetitivos 
3.6. Deferimento de medidas urgentes no recurso especial repetitivo e nos processos suspensos.

3.7. Desistência dos processos suspensos e dos recursos representativos da controvérsia .94

Capítulo 4 - Instrução e julgamento dos recursos especiais repetitivos .96

4.1. Instrução dos recursos representativos da controvérsia.......................................96

4.2. Julgamento do recurso especial repetitivo ........................................................99

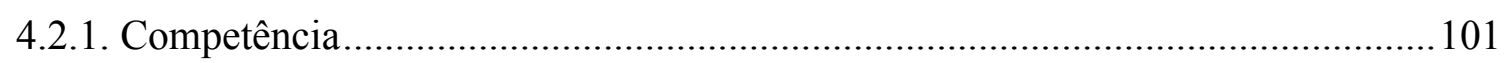

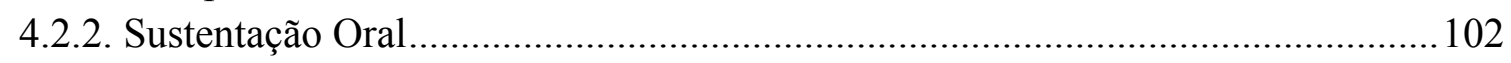

4.2.3. Efeito devolutivo, prequestionamento e necessidade de enfrentamento de todas as

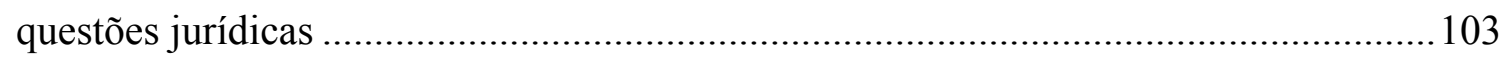

4.2.4. Exame dos fatos e interpretação de cláusula contratual ........................................ 106

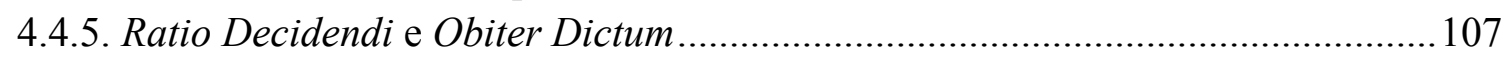

Capítulo 5 - Eficácia e reflexos da decisão do Superior Tribunal de Justiça..................110

5.1. Efeitos do julgamento do recurso especial repetitivo ........................................110

5.1.1. Aplicação das teses firmadas pelo STJ em sede de recurso especial repetitivo... 113

5.1.2. Modulação dos efeitos da decisão do recurso especial repetitivo .......................... 114

5.2. Impugnação das decisões de aplicação do precedente ......................................115

Capítulo 6 - Consequências da aplicação da técnica de julgamento dos recursos especiais repetitivos ........................................................................................117

6.1. Criação dos NUGEPs (Núcleos de Gestão de Precedentes) ................................117

6.2. Efeitos na quantidade de recursos distribuídos no STJ ......................................118

6.3. Respeito aos julgamentos proferidos em recursos representativos de controvérsia pelos juízes e tribunais ..................................................................................120

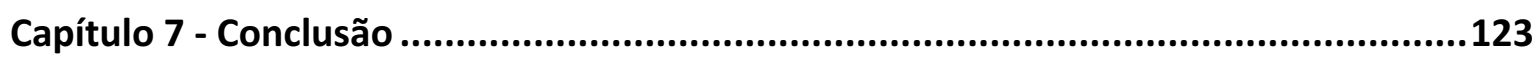

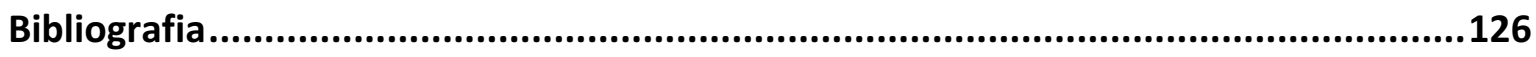




\section{CAPítulo 1 - INTRODUÇão}

\subsection{Justificativa PaRa a CRIAÇão do Sistema de JUlgamentos por AMOSTRAGEM}

O estudo do direito processual desenvolveu-se, tradicionalmente, a partir da análise de litígios individuais. A legislação, do mesmo modo, disciplina tradicionalmente o processo individual, posto que visa a uma cognição exauriente sobre questões particularmente postas e à solução do conflito externado no caso concreto mediante a aplicação singularizada da norma.

Com o passar do tempo, contudo, o Estado se desenvolveu e as relações em sociedade se tornaram mais complexas e muitas vezes massificadas, ficando evidente o déficit do ordenamento jurídico para a proteção de determinados tipos de conflito. Tornouse entendimento assente entre os estudiosos do Direito que novos tipos de conflito surgiam, transbordando a esfera de direitos de um indivíduo em contraposição a outro (direitos supraindividuais), e que a legislação processual voltada à solução de demandas individuais não era suficiente para tutelá-los adequadamente. ${ }^{1}$

Embora as ações coletivas não sejam uma novidade na história do Direito, havendo o registro de "ação popular" já no direito romano ${ }^{2}$ e no período medieval, ${ }^{3}$ o desenvolvimento do sistema de produção e distribuição em série de bens acentuou a necessidade de se disciplinar o processo para as demandas coletivas.

\footnotetext{
${ }^{1}$ Cf. CAPPELletTI, Mauro; GARTH, Bryant. Acesso à justiça, trad. e rev. Ellen Gracie Northfleet, Porto Alegre, Sergio Antonio Fabris Editor, 1998, p. 19.

2 “As ações populares romanas podem ser classificadas (incluindo-se nessa classificação os interdicta $e$ as verdadeiras ações) a partir de diferentes pontos de vista: a) com base no critério da norma que institui e disciplina a ação, as ações 'legais' e as ações 'pretorias'; b) considerando-se a natureza jurídica do meio jurídico utilizado, em interdicta $e$ actiones populares; c) enfim, levando-se em conta o sujeito ao qual é destinada a soma estabelecida na condenação, essas ações dividem-se entre aquelas em que 1) a soma é a favor dos cofres públicos; 2) a soma é a favor do autor popular; e 3) a soma é a favor de um terceiro" (BENARRÓS CLEMENTONI, Myriam. Actio popularis no Direito Romano e sua recepção no Direito Brasileiro, Dissertação de Mestrado, Faculdade de Direito da Universidade de São Paulo, 2016, pp. 2-3).

${ }^{3}$ Apesar de as ações populares continuarem a existir no direito medieval, elas não eram muito utilizadas. (Cf. AFONSO DA SILVA, José. Ação popular constitucional, São Paulo, Revista dos Tribunais, 1968, p. 16).
} 
A partir da experiência americana das class actions, os doutrinadores brasileiros voltaram-se ao estudo de demandas que pudessem tutelar os direitos difusos, coletivos e individuais homogêneos, em busca de soluções para a litigância em massa.

Sobrevieram, então, as Leis nn. 4.717/1965, que regula a ação popular, 7.347/1985, que disciplina a ação civil pública, e 8.429/1992, que trata do mandado de segurança coletivo. Juntos, tais diplomas normativos formam um subsistema próprio que regula as ações coletivas, ao qual se agregam as regras processuais decorrentes do Código de Defesa do Consumidor (Lei n. 8.078/1990).

São leis esparsas, elaboradas em momentos distintos e com finalidades próprias, que não se preocuparam em sistematizar o direito processual coletivo, mas que trouxeram um grande avanço na maneira de se prestar a tutela jurisdicional, já que previram regras específicas para a defesa dos direitos coletivos.

Não obstante esse aparato legislativo, continuaram existindo demandas repetitivas que se multiplicavam e que não eram solucionadas pelas demandas coletivas seja porque (i) não há quantidade suficiente de associações a representar todos os segmentos do país; (ii) há, em alguma medida, restrições para a atuação destas associações (como a exigência de autorização expressa do associado para se beneficiar da decisão); (iii) a ação coletiva não é admitida em alguns casos, como para questionar "tributos, contribuições previdenciárias, o Fundo de Garantia do Tempo de Serviço - FGTS ou outros fundos de natureza institucional cujos beneficiários podem ser individualmente determinado" (LACP, art. $1^{\circ}$, par. único); (iv) o próprio regime jurídico da coisa julgada em ação coletiva propicia muitas vezes o litígio, já que a sentença coletiva não prejudica os direitos individuais (nas ações coletivas que tratam de direitos individuais homogêneos, a coisa julgada opera-se apenas in utilibus, em relação ao titular do direito individual, nos termos do art. 103, III, do $\mathrm{CDC}$ ); ou (v) não tutela direitos individuais similares ou questões processuais repetitivas. ${ }^{4}$

\footnotetext{
${ }^{4}$ Diversos autores descrevem a insuficiência das ações coletivas para a tutela de demandas repetitivas, dentre eles, VIGLIAR, José Marcelo Menezes, “Alguns aspectos sobre a ineficiência do procedimento especial destinado aos interesses individuais homogêneos", in MILARE, Édis (coord.), A ação civil pública após 20 anos: efetividade e desafios, São Paulo, Revista dos Tribunais, 2005, p. 323-329; e SICA, Heitor, "Congestionamento viário e congestionamento judiciário", in https://www.academia.edu/12883899/2015__Congestionamento_vi\%C3\%A1rio_e_congestionamento_judici\%C3\%A1rio, acesso em 09/08/2019.
} 
Ademais, continuou existindo uma forte crença de que a função jurisdicional consistiria na solução de conflitos concretos envolvendo indivíduos ou grupos, e não necessariamente na geração de normas a serem aplicadas para a solução de conflitos concretos que no futuro venham a surgir. ${ }^{5}$ Logo, os precedentes jurisdicionais ainda eram vistos somente como fator de persuasão sobre os julgadores de casos futuros, por mais elevada que fosse a corte judiciária de que proviessem e por mais que se mantivessem estáveis as sucessivas decisões, e não como elemento de exercício do poder, porque não se impunham com força obrigatória.

Assim, nesse cenário anterior à guinada do direito brasileiro em direção à valorização dos precedentes judiciais, muitos problemas práticos ainda subsistiam.

Consequência disso foi a necessidade de criação de uma técnica processual para a solução de questões que se repetem, tanto para aquelas de direito material (individual ou coletivo) quanto para as de direito processual. ${ }^{6}$

Em um primeiro momento, foram realizadas reformas pontuais no Código de Processo Civil de 1973 e na legislação extravagante, com vistas à introdução de técnicas diferenciadas e específicas, que não se confundiam com a dogmática coletiva, mas que buscavam a diminuição da quantidade de processos, a uniformização da jurisprudência de forma mais efetiva, a razoável duração do processo e uma prestação jurisdicional homogênea em todas as matérias, à luz do princípio da isonomia.

Inicialmente, em 2003, o Supremo Tribunal Federal (STF) alterou seu Regimento Interno por meio da Emenda Regimental n. 12, para instituir um sistema de julgamento de recursos extraordinários repetitivos provenientes dos Juizados Especiais Federais. $^{7}$

\footnotetext{
${ }^{5}$ É claro que nesse momento as súmulas persuasivas e as decisões proferidas pelos tribunais superiores já eram relevantes para a solução de casos futuros, mas ainda havia uma grande primazia da lei, suficiente para ofuscar a importância dos precedentes.

${ }^{6}$ Seriam as "demandas seriadas, isomórficas ou pseudo-individuais" (RODRIGUES, Roberto de Aragão Ribeiro, Ações repetitivas: o novo perfil da tutela dos direitos individuais homogêneos, Curitiba, Juruá, 2013, p. 22).

${ }^{7}$ A Emenda Regimental n. 12, de 2003, acrescentou o $\S 5^{\circ}$ ao art. 321 do Regimento Interno do Supremo Tribunal Federal (RISTF), fazendo-o nos seguintes moldes: " $\$ 5^{\circ}$ Ao recurso extraordinário interposto no âmbito dos Juizados Especiais Federais, instituidos pela Lei n. 10.259, de 12 de julho de 2001, aplicam-se as seguintes regras:
} 
Em seguida, a Lei n. 11.418/2007 estendeu o emprego dessa técnica para o julgamento de todos os recursos extraordinários repetitivos, introduzindo no art. 543-B do Código de Processo Civil de 1973 o regime de "julgamento dos recursos representativos da controvérsia". 8

Ato contínuo, a Lei n. 11.672/2008 possibilitou a aglutinação de questões jurídicas comuns aos recursos especiais, ${ }^{9}$ introduzindo o art. 543-C no Código de Processo Civil de 1973. Por meio dessa técnica, eram escolhidos um ou mais recursos para análise e julgamento pelo Superior Tribunal de Justiça (STJ), sobrestando-se nos tribunais superiores e de segunda instância os demais recursos especiais ainda pendentes de julgamento e que

I-verificada a plausibilidade do direito invocado e havendo fundado receio da ocorrência de dano de difícil
reparação, em especial quando a decisão recorrida contrariar súmula ou jurisprudência dominante do
Supremo Tribunal Federal, poderá o relator conceder, de ofício ou a requerimento do interessado, ad
referendum do Plenário, medida liminar para determinar o sobrestamento, na origem, dos processos nos quais
a controvérsia esteja estabelecida, até o pronunciamento desta Corte sobre a matéria; II - o relator, se entender necessário, solicitará informações ao Presidente da Turma Recursal ou ao Coordenador da Turma de Uniformização, que serão prestadas no prazo de 05 (cinco) dias;

III - eventuais interessados, ainda que não sejam partes no processo, poderão manifestar-se no prazo de 30 (trinta) dias, a contar da publicação da decisão concessiva da medida cautelar prevista no inciso I deste $\S 5^{\circ}$;

$I V$ - o relator abrirá vista dos autos ao Ministério Público Federal, que deverá pronunciar-se no prazo de 05 (cinco) dias;

$V$ - recebido o parecer do Ministério Público Federal, o relator lançará relatório, colocando-o à disposição dos demais Ministros, e incluirá o processo em pauta para julgamento, com preferência sobre todos os demais feitos, à exceção dos processos com réus presos, habeas corpus e mandado de segurança;

$V I$ - eventuais recursos extraordinários que versem idêntica controvérsia constitucional, recebidos subsequentemente em quaisquer Turmas Recursais ou de Uniformização, ficarão sobrestados, aguardando-se o pronunciamento do Supremo Tribunal Federal;

VII - publicado o acórdão respectivo, em lugar especificamente destacado no Diário da Justiça da União, os recursos referidos no inciso anterior serão apreciados pelas Turmas Recursais ou de Uniformização, que poderão exercer o juizo de retratação ou declará-los prejudicados, se cuidarem de tese não acolhida pelo Supremo Tribunal Federal;

VIII - o acórdão que julgar o recurso extraordinário conterá, se for o caso, súmula sobre a questão constitucional controvertida, e dele será enviada cópia ao Superior Tribunal de Justiça e aos Tribunais Regionais Federais, para comunicação a todos os Juizados Especiais Federais e às Turmas Recursais e de Uniformização".

${ }^{8}$ Assim dispôs o caput do art. 543-B. "Quando houver multiplicidade de recursos com fundamento em idêntica controvérsia, a análise da repercussão geral será processada nos termos do Regimento Interno do Supremo Tribunal Federal, observado o disposto neste artigo".

9 Trata-se de instituto comumente chamado de "coletivização das demandas individuais" ou aggregate litigation (NAGAREDA, Richard A. The law of Class Actions and other aggregate litigation, Foundation Press, New York, 2009). 
versassem sobre o tema, os quais, ao final, recebiam a mesma solução dada aos casos escolhidos para serem decididos por amostragem. ${ }^{10}$

É claro que o agrupamento de demandas individuais repetitivas não se confunde com as ações coletivas, existindo marcantes diferenças entre os institutos, especialmente no que tange à legitimidade.

Enquanto nas demandas individuais repetitivas a legitimidade é ordinária, posto que o direito material discutido é individual (embora análogo ao direto estampado em outras tantas demandas individuais), nas ações coletivas a legitimidade é essencialmente extraordinária, já que o direito material discutido não é titularizado por um indivíduo, mas pela coletividade. Assim, sob a técnica proposta pela Lei n. 11.672/2008, a solução de várias demandas individuais repetidas é feita de forma otimizada ou concentrada, por meio da seleção de um ou mais casos representativos da controvérsia e da ulterior aplicação da

\footnotetext{
10 “Art. 543-C. Quando houver multiplicidade de recursos com fundamento em idêntica questão de direito,o recurso especial será processado nos termos deste artigo.
}

$\S 1^{\circ}$ Caberá ao presidente do tribunal de origem admitir um ou mais recursos representativos da controvérsia, os quais serão encaminhados ao Superior Tribunal de Justiça, ficando suspensos os demais recursos especiais até o pronunciamento definitivo do Superior Tribunal de Justiça.

$\S 2^{\circ}$ Não adotada a providência descrita no $\S 1^{\circ}$ deste artigo, o relator no Superior Tribunal de Justiça, ao identificar que sobre a controvérsia já existe jurisprudência dominante ou que a matéria já está afeta ao colegiado, poderá determinar a suspensão, nos tribunais de segunda instância, dos recursos nos quais a controvérsia esteja estabelecida.

$\S 3^{\circ}$ O relator poderá solicitar informações, a serem prestadas no prazo de quinze dias, aos tribunais federais ou estaduais a respeito da controvérsia.

$\S 4^{\circ} \mathrm{O}$ relator, conforme dispuser o regimento interno do Superior Tribunal de Justiça e considerando a relevância da matéria, poderá admitir manifestação de pessoas, órgãos ou entidades com interesse na controvérsia.

$\S 5^{\circ}$ Recebidas as informações e, se for o caso, após cumprido o disposto no $\S 4^{\circ}$ deste artigo, terá vista o Ministério Público pelo prazo de quinze dias.

$\S 6^{\circ}$ Transcorrido o prazo para o Ministério Público e remetida cópia do relatório aos demais Ministros, o processo será incluído em pauta na seção ou na Corte Especial, devendo ser julgado com preferência sobre os demais feitos, ressalvados os que envolvam réu preso e os pedidos de habeas corpus.

$\S 7^{\circ}$ Publicado o acórdão do Superior Tribunal de Justiça, os recursos especiais sobrestados na origem:

I - terão seguimento denegado na hipótese de o acórdão recorrido coincidir com a orientação do Superior Tribunal de Justiça; ou

II - serão novamente examinados pelo tribunal de origem na hipótese de o acórdão recorrido divergir da orientação do Superior Tribunal de Justiça.

$\S 8^{\circ} \mathrm{Na}$ hipótese prevista no inciso II do $\S 7^{\circ}$ deste artigo, mantida a decisão divergente pelo tribunal de origem, far-se-á o exame de admissibilidade do recurso especial.

$\S 9^{\circ}$ O Superior Tribunal de Justiça e os tribunais de segunda instância regulamentarão, no âmbito de suas competências, os procedimentos relativos ao processamento e julgamento do recurso especial nos casos previstos neste artigo". 
decisão proferida pelo Superior Tribunal de Justiça aos demais processos que tratem do tema (que ficaram sobrestados ou que ainda serão ajuizados), sem que haja coisa julgada extensiva àqueles que não são parte da demanda analisada como representativa no âmbito do STJ. ${ }^{11}$

O regime de "julgamento dos recursos representativos da controvérsia" do Código de Processo Civil de 1973 foi amadurecido e propiciou a consciência de que o jurisdicionado precisava, cada vez mais, de um modelo moldado às particularidades de um país com bolsões anômalos de poder e assimetria cultural, política e econômica, que pudesse proporcionar a prolação de decisões harmônicas em tempo razoável. Revelou-se, assim, a premente necessidade de se buscar soluções uniformes, previsíveis e céleres para processos repetitivos que contenham controvérsia sobre uma mesma questão jurídica.

Exsurge, então, o anseio de ampliação dessa técnica processual, com vistas a minimizar o risco concreto de ofensa à isonomia e à segurança jurídica que decorre da potencialidade do surgimento de decisões divergentes para casos essencialmente correlatos.

Essa tarefa coube ao Código de Processo Civil de 2015, que aprimorou a solução da questão jurídica (de direito material ou processual) que se repete e declarou a observação obrigatória dessa decisão agora para todas as instâncias, ${ }^{12}$ consolidando uma mudança de paradigma no que toca ao exercício da função nomofilática das Cortes Supremas $^{13}$ (do subjetivo para o objetivo).

${ }^{11}$ BASSETT, Debra Lyn. Constructing class action reality. Brigham Young University Law Review, vol. 2006, issue 6, 2006, p. 1440.

12 “Os arts. 489 \& 1', V e VI, 926 e 927, CPC, devem ser interpretados de modo que o verbo 'observar' signifique 'considerar', 'interpretar' e, em sendo o caso, 'aplicar'. Considerar significa levar em conta os precedentes. Interpretar, adscrever o significado do precedente de acordo com a sua moldura fáticonormativa. Aplicar, retirar consequências jurídicas para o caso concreto. Só não será o caso de aplicar se, e somente se, houver razão para se proceder à distinção ou, havendo competência, à superação do precedente" (MITIDIERO, Daniel. Precedentes: da persuasão à vinculação, 3. ed. rev., atual. e ampl., São Paulo, Revista dos Tribunais, 2018, p. 101).

13 "E é precisamente essa a função que Corte Suprema deve desempenhar: dar unidade ao Direito mediante a sua adequada interpretação a partir do julgamento de casos a ela apresentados. Com isso, a função da Corte Suprema deve desempenhar: dar unidade ao Direito mediante a sua adequada intepretação a partir do julgamento de casos a ela apresentados. Com isso, a função da Corte Suprema é proativa, sendo sua atuação destinada a orientar a adequada interpretação e aplicação do Direito por parte de toda a sociedade civil e de todos os membros do Poder Judiciário. A sua função tem no horizonte o futuro: ela atua de maneira proativa com o fim de guiar a interpretação do Direito, dando a ele unidade" (MITIDIERO, Daniel. Cortes Superiores e Cortes Supremas: do controle à interpretação, da jurisprudência ao precedente, 3. ed. rev., atual. e ampl., São Paulo, Revista dos Tribunais, 2017, p. 79). 
A técnica em vigor, denominada "julgamento de casos repetitivos" (art. 928, CPC/15), confere tratamento prioritário, adequado e racional às questões repetitivas, destinando-se a gerir os casos semelhantes e decidi-los com força de precedente que vincula o próprio tribunal, seus órgãos e os juízos a ele subordinados. ${ }^{14}$

Ao seguirem as decisões proferidas em casos análogos, os magistrados preservam a estabilidade, a integridade e a coerência (art. 926, CPC/15), contribuindo, a um só tempo, para a certeza do direito e para a proteção da confiança que o jurisdicionado depositou no Poder Judiciário.

O Superior Tribunal de Justiça, que é o tribunal responsável pela uniformização da jurisprudência em matéria legal (no âmbito federal), ganha destaque nessa função, ${ }^{15}$ reafirmando sua função primordial e histórica de fixar o sentido das normas federais, o que mostra ser essencial que os precedentes ali formados sejam seguidos pelos órgãos fracionários do próprio STJ, assim como por quaisquer tribunais para casos semelhantes.

Decorre daí a lógica da regra inserta no caput do art. 926 do Código de Processo Civil de 2015, que exalta a função uniformizadora dos tribunais em geral, e das Cortes Superiores em particular. $O \S 1^{\circ}$ do mesmo dispositivo legal estimula os tribunais a criarem súmulas com fundamento na "jurisprudência dominante" da própria Corte. Esta técnica hermenêutica é fundamental para atender à aspiração de estabilidade, integridade e coerência, características que formam um dos pilares que sustentam a técnica dos precedentes vinculantes no Brasil.

\footnotetext{
${ }^{14}$ Trata-se, como visto, de técnica estruturalmente diferente do processo coletivo, na medida em que visa a produzir precedente obrigatório e não a coisa julgada sobre a questão repetitiva.

${ }^{15}$ Como bem ponderou o Exmo. Sr. Ministro Humberto Gomes de Barros quando do julgamento do Agravo Regimental no REsp 228.432/RS: "O Superior Tribunal de Justiça foi concebido para um escopo especial: orientar a aplicação da lei federal e unificar-lhe a interpretação, em todo o Brasil. Se assim ocorre, é necessário que sua jurisprudência seja observada, para se manter firme e coerente. Assim sempre ocorreu em relação ao Supremo Tribunal Federal, de quem o Superior Tribunal de Justiça é sucessor, nesse mister. Em verdade, o Poder Judiciário mantém sagrado compromisso com a justiça e a segurança. Se deixarmos que nossa jurisprudência varie ao sabor das convicções pessoais, estaremos prestando um desserviço a nossas instituições. Se nós - os integrantes da Corte - não observarmos as decisões que ajudamos a formar, estaremos dando sinal, para que os demais órgãos judiciários façam o mesmo. Estou certo de que, em acontecendo isso, perde sentido a existência de nossa Corte. Melhor será extingui-la”.
} 
Considera-se, assim, julgamento de caso repetitivo a decisão proferida em (i) incidente de resolução de demandas repetitivas e (ii) recursos especial e extraordinário repetitivos. $^{16}$

Tais institutos jurídicos compõem o microssistema de gestão e julgamento de casos repetitivos (sujeitando-se às normas relativas a esta gestão, como, por exemplo, a que determina o sobrestamento de processos à espera da decisão paradigma) e também o microssistema de formação concentrada de precedentes obrigatórios (sujeitando-se às normas relativas a esta formação, como as que determinam a ampliação da cognição e da participação, a fundamentação reforçada, a ampla publicidade e a aplicação do precedente). ${ }^{17}$

O tema a ser desenvolvido na presente dissertação coloca em destaque a análise pormenorizada do "recurso especial repetitivo", e busca analisar os contornos que envolvem o procedimento formador das decisões com efeito vinculante provenientes dos julgamentos desses recursos pelo Superior Tribunal de Justiça.

Partindo da premissa de que essa técnica de julgamentos "por amostragem" que forma precedente de aplicação obrigatória é uma realidade no Brasil, pretende-se realizar um estudo analítico dos pontos concernentes à técnica procedimental diretamente ligada ao recurso especial repetitivo, seguido de uma análise crítica do instituto.

A técnica de "julgamento de casos repetitivos" é muito recente e está em pleno desenvolvimento, não apenas perante o Superior Tribunal de Justiça, mas também perante as instâncias inferiores, razão pela qual é fundamental que se reflita sobre como estão sendo assentados os procedimentos e quais devem ser os próximos passos.

A importância do julgamento dos recursos repetitivos vem crescendo bastante em pouco tempo e cabe à comunidade acadêmica acompanhar de perto o desenvolvimento desses trabalhos e direcionar sua consolidação e a evolução da jurisprudência, para que seja permitida a efetiva participação dos interessados, mediante amplos debates em torno das proposições jurídicas necessárias à solução das questões

\footnotetext{
16 “Art. 928. Para os fins deste Código, considera-se julgamento de casos repetitivos a decisão proferida em: I - incidente de resolução de demandas repetitivas; II - recursos especial e extraordinário repetitivos. Parágrafo único. O julgamento de casos repetitivos tem por objeto questão de direito material ou processual”.

${ }^{17} \mathrm{O}$ microssistema de formação de precedentes obrigatórios é integrado também pelo incidente de assunção de competência, que não exige a existência de causas repetitivas para o seu julgamento.
} 
repetitivas. Deve-se ter em mente o caráter supra partes dos recursos representativos da controvérsia, o que confere maior responsabilidade ao Superior Tribunal de Justiça, justificando a exigência da acurada demonstração, em cada caso, da ratio decidendi e de eventual obiter dictum, bem como da adequada aplicação das figuras jurídicas do distinguishing e overruling, que são importantíssimas para o aperfeiçoamento do julgamento por amostragem e para a sua credibilidade perante os jurisdicionados.

Ademais, é imprescindível que o Superior Tribunal de Justiça se ajuste à contemporânea concepção proposta pelo Código de Processo Civil de 2015 para resolver as particularidades dos conflitos existentes no Brasil sob a perspectiva da função pública que exerce, desincumbindo-se da obrigação isolada de proteger o direito subjetivo lesado. ${ }^{18}$ Não é, portanto, a lei que trará essa evolução, mas a consciência de que o Tribunal Superior atua em defesa do ordenamento jurídico objetivo e não para proteger o direito subjetivo dos litigantes.

Afinal, a convergência dos recursos para um tribunal de superposição que não foi criado para ser uma terceira instância somente pode ser explicada pela existência de uma função para além dos interesses das partes, com a geração de segurança jurídica (solução equânime dos casos idênticos), a pacificação social (permitindo que todos possam pautar suas condutas na interpretação firme representada pelos julgamentos dos recursos representativos da controvérsia) e a economia processual.

Um sistema maduro de julgamento dos recursos especiais repetitivos permitirá que o Superior Tribunal de Justiça julgue menos para julgar melhor e é este o

\footnotetext{
${ }^{18}$ Importa destacar o acertado alerta feito por José Miguel Garcia Medina: “(...) qualquer tribunal exerce aquilo que se poderia chamar de função pública, pois, com seu labor, contribui para que se aprimore, pouco a pouco, o sentido de um dado princípio, por exemplo. Diante disso, parece difícil distinguir, em termos definitivos, quanto ao desempenho de tais funções pública e privada, a atuação de tribunais de cúpula - como, entre nós, o Supremo Tribunal Federal e o Superior Tribunal de Justiça - e os demais tribunais, que julgam recursos interpostos contra decisões proferidas por juizes de $1^{\circ}$ grau. Essa distinção e a tendência em se atribuir, ainda que de modo preponderante, a função pública aos tribunais superiores e a função privada aos demais tribunais, acaba por ocultar uma realidade que não pode ser afastada: a identificação do sentido da norma jurídica - isto é, o labor consistente em interpretar e aplicar textos e princípios com o fim de se definir a inteligência da norma jurídica - é algo com que se ocupam todos os juízes, e não apenas os juízes de tribunais superiores, como se disse. (...). Dizendo de outro modo, a 'função pública' não é exclusiva dos tribunais superiores. Isso se agrava, sobretudo, quando se restringe o acesso a esses tribunais, o que acaba ampliando, necessariamente, o âmbito de atuação dos demais órgãos jurisdicionais” (MEDINA, José Miguel Garcia. Prequestionamento, repercussão geral da questão constitucional, relevância da questão federal: admissibilidade, processamento e julgamento dos recursos extraordinário e especial, $7^{\mathrm{a}}$ ed. rev., ampl. e atual., São Paulo, RT, 2017, p. 40).
} 
caminho legalmente assegurado hoje para que se busque um Tribunal eficiente e cumpridor da sua elevada e importante posição dentro do sistema.

\subsection{DEMANDAS REPETITIVAS}

Como visto, convivem com os conflitos de natureza eminentemente individual os conflitos heterogêneos de natureza coletiva, os conflitos homogêneos individuais e coletivos ${ }^{19}$ que contêm causas de pedir e pedidos semelhantes, e os conflitos heterogêneos individuais e coletivos que possuem questões comuns. ${ }^{20}$

Assim, antes de se adentrar no estudo do tema propriamente dito, é indispensável a definição daquilo que o ordenamento jurídico convencionou chamar de “demanda repetitiva" para fins de sujeição à sistemática dos recursos especiais repetitivos.

Segundo o Conselho Nacional de Justiça (CNJ), "demandas repetitivas são processos nos quais a mesma questão de direito se reproduz de modo que a sua solução pelos Tribunais Superiores ou pelos próprios Tribunais locais pode ser replicada para todos, de modo a garantir que essas causas tenham a mesma solução, ganhando-se, assim, celeridade, isonomia e segurança jurídica no tratamento de questões com grande

\footnotetext{
${ }^{19}$ Lembra Eduardo Talamini que "é possivel que uma mesma questão de direito ponha-se repetidamente em diversas ações coletivas para tutela de direito difuso coletivo em sentido estrito (por ex., seccionais da OAB de diferentes unidades da Federação promovem ações coletivas para que se reconheça determinado direito da classe dos advogados, no âmbito de suas respectivas seções). Temos nessa hipótese algo que se poderia qualificar como direitos coletivos homogêneos" (TALAMINI, Eduardo. "A dimensão coletiva dos direitos individuais homogêneos: ações coletivas e os mecanismos previstos no Código de Processo Civil de 2015", in DIDIER JR., Fredie; CUNHA, Leonardo Carneiro da (coord.), Julgamento de casos repetitivos, Salvador, Juspodivm, 2017, p. 162).

${ }^{20}$ Sofia Temer faz uma detida análise dos direitos individuais homogêneos, com a finalidade de identificar se eles são "compreendidos como uma categoria autônoma, de natureza coletiva, já que tal conclusão poderia apontar pela inviabilidade de equipará-los com os direitos veiculados via processos repetitivos, uma vez que a tutela propriamente coletiva seria necessária e excludente" (p. 45). Ao final, a autora conclui que apesar de compartilhar de tal preocupação, "a utilização da via coletiva não é suficiente para justificar uma outra dimensão (material) para os direitos individuais homogêneos. Entendemos, então, que os direitos individuais homogêneos não são 'materialmente' coletivos. Assim sendo, sua natureza não impede, a princípio, que sejam equiparados aos direitos veiculados via processos individuais repetitivos" (p. 52) (Sofia Temer. Incidente de Resolução de Demandas Repetitivas, 3. ed., rev. e ampl., Salvador, Juspodivm, 2018).
} 
repercussão social". ${ }^{21}$ Esse pensamento está em consonância com o que se extrai dos arts. 928, par. único, 976 e 1036 do Código de processo Civil. ${ }^{22}$

Portanto, não se trata propriamente de "demandas repetidas" (considerando-se que a demanda é, para a grande maioria da doutrina, "o ato de postulação que encerra uma pretensão processual, informada por seus três elementos: partes, pedido e causa de pedir, tendo como objetivo um bem da vida disputado entre as partes no mesmo plano material"), ${ }^{23}$ mas de "questões jurídicas repetidas".

Com efeito, o diploma processual alude a demandas que contenham "questões de direito similares", como aquelas estritamente processuais que se replicam em processos absolutamente distintos no tocante às pretensões substanciais, ou aquelas que contenham pontos comuns de direito material, mesmo quando o objeto dos processos é diverso (ações coletivas repetitivas com demandas heterogêneas). ${ }^{24}$

Assim, as "demandas" são consideradas repetidas para fins de julgamento a partir do recurso especial representativo da controvérsia mesmo quando apenas uma ou algumas questões de direito material ou processual ali discutidas sejam homogêneas.

Não há, entretanto, que se confundir as questões objeto dos recursos especiais repetitivos com os direitos individuais homogêneos. Estes são direitos subjetivos individuais semelhantes detidos por inúmeros indivíduos. Em razão dessa semelhança, eles

\footnotetext{
${ }^{21}$ - in https://www.cnj.jus.br/pesquisas-judiciarias/demandas-repetitivas/, acesso em 23/10/2019.

22 “Art. 928. Para os fins deste Código, considera-se julgamento de casos repetitivos a decisão proferida em: (...).
}

Parágrafo único. O julgamento de casos repetitivos tem por objeto questão de direito material ou processual”.

“Art. 976. É cabivel a instauração do incidente de resolução de demandas repetitivas quando houver, simultaneamente: I- efetiva repetição de processos que contenham controvérsia sobre a mesma questão unicamente de direito; II- risco de ofensa à isonomia e à segurança jurídica."

“Art. 1.036. Sempre que houver multiplicidade de recursos extraordinários ou especiais com fundamento em idêntica questão de direito, haverá afetação para julgamento de acordo com as disposições desta Subseção, observado o disposto no Regimento Interno do Supremo Tribunal Federal e no do Superior Tribunal de Justiça" (grifou-se).

${ }^{23}$ SICA, Heitor Vitor Mendonça. O direito de defesa no processo civil brasileiro, São Paulo, Atlas, 2011, p. 85.

${ }^{24}$ Marcos Cavalcanti bem reconhece que "a similitude de causas de pedir e pedidos não é fator determinante para a caracterização de um processo como repetitivo. Esses processos identificam-se no plano abstrato por discutirem, em larga escala, questões jurídicas de origem comum homogêneas que podem surgir ainda que não exista qualquer similaridade entre os elementos das demandas" (CAVALCANTI, Marcos. Incidente de resolução de demandas repetitivas e ações coletivas, Salvador, Juspodivm, 2015, p. 527). 
podem ser tutelados de maneira coletiva (são passíveis de serem agrupados para uma tutela conjunta). ${ }^{25}$ Para tanto, basta que haja uma origem comum e a preponderância de questões homogêneas em relação às pretensões divisíveis e subjetivamente determinadas de cada um dos interessados. ${ }^{26}$

As demandas repetitivas, por sua vez, trazem questões jurídicas repetidas, que "podem ser comuns a inúmeros direitos, relações e situações jurídicas de estrutura muito heterogênea, mas no bojo dos quais haja um estrato comum da discussão. Não há comunhão de direitos nem a mesma causa de pedir ou pedido". ${ }^{27}$ Assim, não é necessário que tenham origem comum, tampouco que haja a prevalência de questões comuns sobre os particulares, como se exige na ação coletiva que versa sobre direito individual homogêneo. ${ }^{28}$

Nessa medida, enquanto o processo coletivo enfrenta inúmeras dificuldades para tutelar os interesses coletivos de forma isonômica, previsível e estável, esta função vai sendo exercida pelas novas técnicas trazidas pelo Código de Processo Civil de 2015, que se aplicam, inclusive, ao próprio processo coletivo. ${ }^{29}$

25 "Com efeito, o Código de Proteção e Defesa do Consumidor introduziu mecanismo especial para defesa
coletiva dos chamados direitos individuais homogêneos, categoria de direitos não raro confundida com os
direitos coletivos e difusos e por isso mesmo lançada com eles em vala comum, como se lhes fossem comuns e
idênticos os instrumentos processuais de defesa em juizo. Porém, é preciso que não se confunda defesa de
direitos coletivos (e difusos) com defesa coletiva de direitos (individuais). Direito coletivo é direito
transindividual (= sem titular determinado) e indivisivel. Pode ser difuso ou coletivo stricto sensu. Já os
direitos individuais homogêneos são, na verdade, simplesmente direitos subjetivos individuais. A qualificação
de homogêneos não desvirtua essa sua natureza, mas simplesmente os relaciona a outros direitos individuais
assemelhados, permitindo a defesa coletiva de todos eles" (ZAVASCKI, Teori Albino. Defesa de direitos
coletivos e defesa coletiva de direitos, in http://www2.senado.leg.br/bdsf/handle/id/176342, acesso em
$01 / 10 / 2019, \mathrm{p}$. 84). ${ }^{26}$ A proteção coletiva dos direitos individuais deve atender aos "requisitos da prevalência das questões de direito e de fato comuns sobre as questões de direito ou de fato individuais e da superioridade da tutela coletiva sobre a individual em termos de justiça e eficácia da sentença" (MENDES, Aluisio Gonçalves de Castro. Ações coletivas e meios de resolução coletiva de conflitos no direito comparado e nacional, 3. ed., São Paulo, Revista dos Tribunais, 2012, p. 221).

${ }^{27}$ CABRAL, Antonio do Passo. “Comentários aos arts. 976 a 987”, in CABRAL, Antonio do Passo; CRAMER, Ronaldo, Comentários ao novo Código de Processo Civil, Rio de Janeiro, Forense, 2015, p. 1420.

${ }^{28}$ A sistemática dos recursos repetitivos não é um aprimoramento da tutela coletiva, pois as técnicas são distintas: "enquanto a tutela coletiva se justifica por razões de facilitação do acesso à justiça, economia processual, preservação da isonomia processual, segurança jurídica ou dificuldade na formação do litisconsórcio, a tutela pluri-individual visa imediatamente a dois objetivos principais: eficiência do Poder Judiciário e preservação da igualdade perante a lei" (DANTAS, Bruno. Teoria dos recursos repetitivos: tutela pluri-individual nos recursos dirigidos ao STF e ao STJ (arts. 543-B e 543-C do CPC), São Paulo, Revista dos Tribunais, 2015, p. 76).

29 "Diante da instauração de um IRDR, inclusive ações coletivas serão sustadas e terão seu resultado subordinado ao que vier a se decidir no incidente...". Ademais, elas "não se submetem a limitações de matérias (p. ex., são utilizáveis para resolver inclusive questões sobre matéria tributária, previdenciária, e de FGTS, que pretensamente estariam proibidas no âmbito da tutela coletiva...). A ação coletiva para a tutela dos 
Não se podem perder de vista que os princípios constitucionais e a defesa do Estado Democrático de Direito, assim como todos os demais requisitos exigidos para o conhecimento dos recursos especiais, não são excetuados pelo simples fato de os recursos especiais pinçados para julgamento representarem controvérsias repetitivas. ${ }^{30}$

Também não há que se afastar das demandas repetitivas a análise de questões jurídicas que tenham estreita relação com os fatos (até porque toda questão jurídica compreende, necessariamente, questão de fato e de direito que se entrelaçam em um todo). ${ }^{31}$ 32

Quando o Código de Processo Civil alude a questões "unicamente de direito", não quer dizer que apenas as questões meramente de direito possam ser julgadas como repetitivas, mas, por óbvio, o legislador objetivou que a análise dos recursos especiais repetitivos ocorra com foco nas questões jurídicas que já contem com um quadro fático predefinido, pois o contrário escaparia da função primordial do Superior Tribunal de Justiça de uniformizar a interpretação da lei federal em todo o território nacional.

O importante na compreensão de questões jurídicas idênticas (para fins do julgamento da causa-piloto como recurso especial repetitivo pelo STJ) é que se elas estiverem ligadas a fatos, estes devem ser tidos por incontroversos pelas instâncias ordinárias

direitos individuais homogêneos corre o risco de ficar em segundo plano" (TALAMINI, Eduardo. "A dimensão coletiva dos direitos individuais homogêneos: ações coletivas e os mecanismos previstos no Código de Processo Civil de 2015”, in DIDIER JR., Fredie; CUNHA, Leonardo Carneiro da (coord.), Julgamento de casos repetitivos, Salvador, Juspodivm, 2017, p. 166).

${ }^{30}$ Luiz Guilherme Marinoni enfatiza a necessidade de os recursos especiais representativos da controvérsia estarem enquadrados nas hipóteses de cabimento constitucionalmente previstas, não sendo cabíveis apenas pelo fato de serem repetitivos: "Imaginar que casos repetitivos, apenas por isso, possam abrir oportunidade à atuação do Supremo Tribunal Federal e do Superior Tribunal de Justiça não tem qualquer cabimento. Isso significaria completo desvirtuamento das funções destas Cortes Supremas. Faria supor que têm a função de definir critérios para a facilitação da resolução dos casos que se repetem” (MARINONI, Luiz Guilherme. Precedentes obrigatórios, 6. ed., rev., atual. e ampl., São Paulo, Revista dos Tribunais, 2019, p. 328).

${ }^{31}$ NEVES, Antonio Castanheira. "A distinção entre a questão-de-facto e a questão-de-direito e a competência do Supremo Tribunal de Justiça como tribunal de revista”, in: Digesta, vol. 1, Escritos acerca do direito, do pensamento jurídico, da sua metodologia e outros, Coimbra, 2011, p. 498-499).

${ }^{32}$ Alguns pressupostos de fato são tão relevantes quanto os pressupostos jurídicos, sendo impossível, nesses casos, aplicar o direito à espécie abstraindo o elemento de fato que o condiciona, sob pena "de uma equivocada valoração das provas resultar na errônea aplicação do direito, porque o direito aplicado ao caso concreto não corresponderá à vontade abstrata da lei", conforme adverte Nelson Luiz Pinto, para arrematar que "se o juiz, ao apreciar os fatos e as provas, a eles aplica uma lei inaplicável, aplica mal a lei aplicável ou não a aplica, ou, mesmo, se ele se engana sobre a existência, validade ou significado de uma norma jurídica, comete, segundo José Afonso da Silva, erro de direito in iudicando. É, ainda, erro de direito in iudicando, passível de ser eventualmente corrigido pelo recurso extraordinário, o que se comete na qualificação jurídica dos fatos provados" (PINTO, Nelson Luiz, Recurso especial para o STJ, 2. ed., São Paulo, Malheiros, 1996, p. 164). 
e devem ser juridicamente equivalentes, ${ }^{33}$ de forma que a discussão esteja inserida no mesmo contexto (ainda que existam pequenas diferenças fáticas que não alterem a questão jurídica a ser efetivamente resolvida). ${ }^{34}$

Tal pensamento está com consonância com a lógica do sistema, já que a total desconexão entre os fatos e o direito pode acarretar sérios problemas na aplicação da tese que advém do julgamento do recurso especial repetitivo. Afinal, a se entender a questão de direito apenas como aquela que exsurge independentemente da análise de qualquer fato envolvido, ter-se-á uma vala comum entre os processos "semelhantes", de maneira que uma tese sobre o dever de prestar alimentos, por exemplo, seja aplicada indistintamente a qualquer causa que trate de alimentos, mesmo que outras tantas questões peculiares sejam abordadas de maneira distinta no âmbito dos diferentes processos.

\footnotetext{
33 "A necessidade de separar fato e direito para legitimar a função de um órgão judicial ou de uma técnica processual fez surgir a suposição de que a questão é de direito se apenas um fundamento de direito é posto em dúvida no processo e, depois, deu origem à noção de que existiria questão de direito quando, não obstante a clara e estreita relação do direito com os fatos, esses não necessitassem ser provados ou valorados. (...). Tendo em vista que o incidente de resolução está preocupado com a definição de 'questões idênticas' (art. 985 do CPC/2015), é certo que o art. 976, ao aludir a 'questão unicamente de direito', não quis proibir a resolução de questões de direito que repousem sobre fatos, mas desejou evidenciar que o incidente não pode ser invocado quando é necessário elucidar matéria de fato" (MARINONI, Luiz Guilherme. Incidente de resolução de demandas repetitivas: decisão de questão idêntica x precedente, São Paulo, Revista dos Tribunais, 2016, p. 53-54). Ainda no mesmo sentido, assim ensina Castro Nunes: "quando se diz que o Supremo Tribunal, no julgamento do recurso extraordinário, não julga questões de fato nem aprecia provas, expressa-se uma verdade, um postulado da teoria desse recurso. Mas cumpre entender em termos essa abstenção: o Tribunal Supremo não julga os fatos, não julga as provas produzidas, aceita estas como aqueles nos termos em que os pôs o julgado recorrido. Mas não abstrai desses elementos quando a regra legal assenta num pressuposto de fato, reconhecido como provado, ou não controvertido nos autos. Em tais casos não é possível declarar o direito sem o fato que o condiciona. Se o julgado local não teve como provado o fato, por ausência ou defeito de prova, falta ao direito invocado um pressuposto que ao Supremo Tribunal não cabe apreciar nem estabelecer, porque soberana é, nessa parte, a justiça local. Mas se acerca do fato não se controverteu ou se o julgado local liquidou a controvérsia, não há porque deixar de julgar a questão de direito porque esta envolva um pressuposto de fato" (CASTRO NUNES, José de. Teoria e prática do poder judiciário, Rio de Janeiro, Forense, 1943, pp. 357-358).

${ }^{34}$ No exemplo de Luiz Guilherme Marinoni: "quando se tem em conta, por exemplo, a responsabilidade pelo fato do produto, podem existir diversos atos de compra e venda e diferentes modos mediante os quais produtos foram utilizados. Quando tais fatos não são controvertidos e surge a questão de saber se o produtor é responsável pelos danos provocados pelo uso do produto, há uma mesma questão de direito. Embora os fatos das demandas repetitivas possam ser visualizados como diferentes na perspectiva do que acontece na realidade, há identidade jurídica entre eles, na medida em que todos fazem ver um fato danoso decorrente do uso do produto. (...). Perceba-se, ainda, que se em determinada ação o produtor contestar a relação entre o uso do produto e o dano, afirmando, por exemplo, que o dano alegado não poderia ter sido produzido mediante o uso do produto, não haverá como supor que esta ação reclama apenas a resolução de uma questão de direito. Essa questão só se tornaria importante para esta específica demanda se a prova produzida - então necessária $n$ ação individual - determinasse que o fato efetivamente decorreu do uso do produto. Significa que, num caso como esse, não há como se pensar em demandas repetitivas" - MARINONI, Luiz Guilherme, Incidente de resolução de demandas repetitivas: decisão de questão identica x precedente, São Paulo, Revista dos Tribunais, 2016, pp. 57-58 - grifou-se).
} 
Nesse contexto, deve-se analisar o grau de predominância do aspecto jurídico da questão, já que uma vez aplicada nas instâncias inferiores a norma errônea aos fatos narrados, a discussão acerca deles será jurídica e isso possibilitará sua reavaliação pela via do recurso especial, visando à correção das ilegalidades verificadas sem que se percam de vista os fatos apurados nos autos do processo. ${ }^{35}$ Mas, havendo necessidade de se fazer nova subsunção dos fatos à lei, mediante o reexame do conjunto fático-probatório produzido, a questão será meramente fática ${ }^{36}$ e essa, efetivamente, não deve ser apreciada pelo Superior Tribunal de Justiça, já que transcende a função constitucionalmente prevista para esta corte. $^{37}$

Finalmente, é preciso lembrar que o Código de Processo Civil de 2015 também alude à "multiplicidade de recursos extraordinários ou especiais". A multiplicidade é o caráter daquilo que é múltiplo, ou seja, do que se apresenta em quantidade significativa, repetida, plural.

Muito embora a própria noção de recurso repetitivo já remeta à "multiplicidade", o legislador quis deixar expressa a necessidade de abundância de processos "com fundamento em idêntica questão de direito", mas não fixou um número mínimo de "causas" que contenham questões repetidas para que se possa invocar a aplicação da sistemática de julgamentos por amostragem.

Assim, como será explorado neste trabalho, caberá ao julgador identificar se a matéria é recorrente e qual é o seu espectro, a fim de estabelecer, caso a caso, a possibilidade de se afetar um determinado tema como repetitivo (representatividade quantitativa). Deverá, ainda, ser devidamente verificada a admissibilidade do recurso e a

${ }^{35}$ Compete à Corte Suprema, portanto, examinar o caso apresentado em juízo sem qualquer distinção entre fato e norma. A Corte Suprema analisa os fatos à luz das normas, dada sua recíproca implicação, snedo vedado tão somente valorá-los do ponto de vista probatório de forma diversa daquela realizada pela instância ordinária. E isso porque é essencial à sua função tomar o caso em toda sua inteireza para - a partir deleinterpretar o Direito levando em consideração todas as suas condicionantes lógico-argumentativas" (MITIDIERO, Daniel. Cortes Superiores e Cortes Supremas: do controle à interpretação, da jurisprudência ao precedente, 3. ed. rev., atual. e ampl., São Paulo, Revista dos Tribunais, 2017, p. 78)

${ }^{36}$ No mesmo sentido, João Francisco Naves da Fonseca ensina que "a valoração jurídica da prova consiste no confronto dos elementos de prova com as regras instituidas pelo direito objetivo em relação a eles", isto é, "vício de atividade (ou de julgamento) ligado à infringência da regra de direito probatório" (FONSECA, João Francisco Naves da. Exame dos fatos nos recursos especial e extraordinário, Dissertação de mestrado, USP, São Paulo, 2010, p. 110).

${ }^{37}$ ALVIM, Teresa Arruda. "Distinção entre questão de fato e questão de direito para fins de cabimento de recurso especial”, in Revista de Processo, v. 23 (out/1998), São Paulo, Revista dos Tribunais, 1998, pp. 53-57. 
existência de extensa argumentação, ou seja, fundamentação abrangente, capaz de representar adequadamente os vários posicionamentos externados sobre o tema em debate (representatividade qualitativa). ${ }^{38}$

38 " $O$ due process of law das demandas repetitivas exige a representatividade argumentativa, isto é, que os vários sujeitos que debatem a questão tenham seus argumentos examinados no procedimento de formação de precedente; pouco importa sua participação direta nele, basta que seus argumentos sejam avaliados pelo órgão judicial responsável pela formação de precedente" (MACÊDO, Lucas Buril. Precedentes judiciais e o Direito Processual Civil, 2. ed. rev., ampl. e atual., Salvador, Juspodivm, 2017, p. 438). 


\section{CAPÍtulo 7 - ConClusão}

As novas leis processuais, somadas à reforma constitucional que introduziu a súmula vinculante no ordenamento jurídico brasileiro, demonstram o contínuo investimento nos mecanismos de uniformização de jurisprudência. Assim, apesar do simples propósito - aparente - de combater a morosidade que norteou tais reformas, o reflexo é a possiblidade de aprimoramento dos métodos destinados a homogeneizar a aplicação da lei. Conclui-se, assim, que os novos mecanismos de vinculação jurisprudencial têm um propósito mais amplo, no sentido de abreviar o tempo necessário ao julgamento de questões jurídicas repetitivas (busca do princípio da economia processual) e de garantir a harmonia interpretativa diante de uma mesma hipótese fática (segurança jurídica a garantir a obediência ao princípio da igualdade).

A dificuldade de identificação dos casos semelhantes em que a mesma solução deverá ser adotada mostra-se como um grande obstáculo à consecução desse objetivo e, por isso, uma mudança cultural quanto às técnicas de formação da ratio decidendi e da motivação das decisões que tratam da distinção (distinguishing) se faz urgente, para que seja viável a devida aplicação dos novos mecanismos de vinculação jurisprudencial, com o fim de se alcançar a celeridade do Judiciário com justiça e paz social. Por tal razão, verificase também o elevado valor do estudo da identificação do caso precedente ou do paradigma.

Os recursos especiais repetitivos têm uma função bastante abrangente no direito brasileiro, abrindo a porta para diversas técnicas de aceleração dos julgamentos e da própria entrega da tutela jurisdicional célere, uniforme e justa. Impende formar-se uma nova cultura, um pensamento único ou predominante dos tribunais de sobreposição e a aceitação dos precedentes vinculantes pelos juízes de primeiro grau e desembargadores.

Essencial, portanto, a criação de institutos e o desenvolvimento de técnicas processuais e gerenciais que visem a eficácia do sistema de julgamento das questões jurídicas a partir dos recursos especiais representativos da controvérsia, de forma que as decisões ali proferidas (no exercício da função nomofilática) tenham a qualidade e representatividade previstas pela lei e vinculem efetivamente os demais tribunais e juízes de primeiro grau. Esse é o caminho para a garantia de um sistema jurisdicional dotado de maior segurança jurídica dentro de um modelo mais célere e econômico. 
Não há, no âmbito das decisões judiciais com caráter vinculante, uma invasão do Poder Judiciário à função constitucionalmente destinada ao Poder Legislativo, afinal, trata-se de interpretação dos textos legais realizada em perfeita consonância com as funções jurisdicionais também estabelecidas pela Constituição de 1988. Resta evidente que o fim primordial da jurisdição, é, no sistema de legalidade, o de fazer observar o direito objetivo em seus preceitos individualizados". 228

A interpretação uniforme da norma jurídica mostra-se como elemento fundamental ao alcance da pacificação social e é esse o resultado que se espera a partir da consolidação do sistema de julgamento de recursos repetitivos pelo Superior Tribunal de Justiça. Afinal, vive-se um momento muito peculiar no sistema jurisdicional brasileiro, uma vez que, ao mesmo tempo em que urge a criação de uma dogmática própria para o dimensionamento das demandas seriais ou repetitivas, tal sistema deve, com as ferramentas e dogmática existentes, resolver os problemas que essa litigiosidade em massa gera. Esse resultado só pode ser alcançado através do desenvolvimento responsável e engajado das técnicas aplicáveis aos institutos geradores dos precedentes vinculantes e de técnicas gerenciais devidamente utilizadas dentro dos órgãos jurisdicionais. ${ }^{229}$

Por fim, também é relevante observar que a obrigatoriedade da fundamentação das decisões judiciais - reforçada no CPC/15 - afasta o pensamento de que os precedentes vinculantes podem ser formados de forma arbitrária. ${ }^{230}$ A função normativa que recai sobre as decisões judiciais exige o estudo de uma teoria adequada da justificação, porquanto é na condição das justificativas para decisões que os votos de juízes são normativos, e apenas de forma normativa eles podem guiar a interpretação do Direito. Daí porque o processo de tomada de decisão judicial deve ser orientado pelos mesmos valores que densificam o princípio do contraditório, tão caro ao Código de Processo Civil de 2015, e o princípio do Estado de Direito, em especial aqueles concernentes à produção das normas jurídicas. $^{231}$

\footnotetext{
${ }^{228}$ Cf. CALAMANDREI, Piero. Direito processual civil, vol. I, trad. Luiz Abezia e Sandra Drina Fernandez Barbiery, Campinas, Bookseller, 1999, p. 145.

${ }^{229}$ Cf. BAHIA, Alexandre Melo Franco. Recursos extraordinários no STF e no STJ, Curitiba, Juruá, 2016, p. 184.

${ }^{230}$ Cf. MARINONI, Luiz Guilherme, ARENHART, Sérgio Cruz e MITIDIERO Daniel. O novo processo civil, 2. ed., São Paulo, Revista dos Tribunais, 2016, p. 114.

${ }^{231}$ Cf. PEREIRA, Paula Pessoa. Legitimidade dos precedentes - universalidade das decisões do STJ. São Paulo, Revista dos Tribunais, 2014, p. 136.
} 
De resto, o movimento de julgamento com base em precedentes vinculantes (com a devida consolidação das técnicas referentes à aplicação dos recursos especial repetitivos pelo Superior Tribunal de Justiça) não prejudica o acesso à justiça; ao contrário, dá mais credibilidade à forma como as decisões serão tomadas pelo Poder Judiciário (segurança jurídica e isonomia) e, ainda, tendem a dotar de celeridade a entrega da prestação jurisdicional (economia processual), tão morosa e cara nos dias de hoje.

Nesse ponto, aliás, verifica-se que a lentidão do Judiciário atualmente caracteriza, em algumas situações, uma verdadeira vedação do acesso à justiça. Não basta a garantia dos meios processuais de acesso ao Poder Judiciário, se na prática a entrega da prestação jurisdicional fica em segundo plano. ${ }^{232}$

Nesse sentido, a análise dos princípios da segurança jurídica (isonomia) e da economia processual foram os grandes balizadores da instituição do sistema de precedentes vinculantes no Brasil. Evidentemente, os maiores cuidados que se devem ter são a observância do princípio do contraditório na aplicação das técnicas processuais referentes à instrução dos recursos especiais representativos da controvérsia perante o Superior Tribunal de Justiça e a responsável, técnica e profunda motivação das decisões judiciais: tanto das que julgam as questões jurídicas repetitivas quanto as que apreciam as impugnações de distinção.

${ }^{232}$ Cf. VIANA, Ulisses Schwarz. Repercussão geral sob a ótica dos sistemas de Niklas Luhmann, São Paulo, Saraiva, 2010, p. 53. 


\section{BIBLIOGRAFIA}

AFONSO DA SILVA, José. Ação popular constitucional, São Paulo, Revista dos Tribunais, 1968.

. Do recurso extraordinário no direito processual brasileiro, São Paulo, Revista dos Tribunais, 1963.

. Comentário Contextual à Constituição, São Paulo, Malheiros, 2006.

ALEXY, Robert. Teoria dos direitos fundamentais, 2. ed., São Paulo, Malheiros, 2015.

ALVIM, Teresa Arruda. "Distinção entre questão de fato e questão de direito para fins de cabimento de recurso especial", in Revista de Processo, v. 23 (out/1998), São Paulo, Revista dos Tribunais, 1998.

ALVIM, Teresa Arruda. Omissão judicial e embargos de declaração, São Paulo, Revista dos Tribunais, 2005.

; DANTAS, Bruno. Recurso especial, recurso extraordinário e a nova função dos tribunais superiores no direito brasileiro, 3. ed. rev., atual. e ampl., São Paulo, Revista dos Tribunais, 2016.

ASSIS, Araken de. Manual dos recursos. 8. ed. rev., atual. e ampl., São Paulo, Revista dos Tribunais, 2016.

. Teoria da segurança jurídica. São Paulo, Malheiros, 2016.

. Moralidade, Razoabilidade e Eficiência na Atividade Administrativa. Belo Horizonte, Revista Brasileira de Direito Público, ano 1, n. 1, abr-jun/2003.

BAHIA, Alexandre Melo Franco. Recursos extraordinários no STF e no STJ. Curitiba, Juruá, 2016.

BALEEIRO, Aliomar. O Supremo Tribunal Federal, esse outro desconhecido, Rio de Janeiro, Forense, 1968.

BAPTISTA DA SILVA, Ovídio. Curso de Processo Civil, vol. 1., 7. ed. ver. e atual., Rio de Janeiro, Forense, 2005.

BARBOSA MOREIRA, José Carlos. Comentários ao Código de Processo Civil, vol. V, 15. ed., Rio de Janeiro, Forense, 2009.

BARBOSA MOREIRA, José Carlos, "A Emenda Constitucional n. 45 e o processo", in Revista Forense, Rio de Janeiro, Forense, v. 102, n. 383, pp. 181-191, jan-fev/2006.

O novo processo civil brasileiro: exposição sistemática do procedimento.

28. ed., Rio de Janeiro, Forense, 2010. 
. Comentários ao Código de Processo Civil, lei 5.869, de 11 de janeiro de 1973, vol. V, arts. 475 a 565, Rio de Janeiro,Forense, 2013.

BASSETT, Debra Lyn. Constructing class action reality. Brigham Young University Law Review, vol. 2006, issue 6, 2006.

BEDAQUE, José Roberto dos Santos. Direito e processo: influência do direito material sobre o processo, 6. ed. rev. e ampl., São Paulo, Malheiros, 2011.

BENARRÓS CLEMENTONI, Myriam. Actio popularis no Direito Romano e sua recepção no Direito Brasileiro, Dissertação de Mestrado, Faculdade de Direito da Universidade de São Paulo, 2016.

BONDIOLI, Luis Guilherme Aidar. "Dos recursos", in Comentários ao código de processo civil, vol. XX, São Paulo, Saraiva, 2016.

BUZAID, Alfredo, "Uniformização da jurisprudência", in AJURIS: Revista da Associação dos Juízes do Rio Grande do Sul, Porto Alegre, Associação dos Juízes do Rio Grande do Sul, v. 34, pp. 190-217, jul/1985.

CABRAL, Antonio do Passo. "A escolha da causa-piloto nos incidentes de resolução de processos repetitivos", in DIDIER JR., Fredie; CUNHA, Leonardo Carneiro da (coord.), Julgamento de casos repetitivos, Salvador, Juspodivm, 2017.

. “Comentários aos arts. 976 a 987”, in CABRAL, Antonio do Passo; CRAMER, Ronaldo, Comentários ao novo Código de Processo Civil, Rio de Janeiro, Forense, 2015.

Coisa julgada e preclusões dinâmicas: Entre continuidade, mudança e transição de posições processuais estáveis, Salvador: Juspodivm, 2013.

CALAMANDREI, Piero. Direito processual civil, vol. I, trad. Luiz Abezia e Sandra Drina Fernandez Barbiery, Campinas, Bookseller, 1999.

CÂMARA, Alexandre Freitas. Levando os padrões decisórios a sério: formação e aplicação de precedentes e enunciados de súmula, São Paulo, Atlas, 2018.

CANOtIlHO, José Joaquim Gomes. Direito Constitucional e teoria da Constituição, Coimbra, Almedina, 1998

CAPPELLETTI, Mauro; GARTH, Bryant. Acesso à justiça, trad. e rev. Ellen Gracie Northfleet, Porto Alegre, Sergio Antonio Fabris Editor, 1998.

CARNEIRO, Athos Gusmão. Recurso especial, agravos e agravo interno. 7. ed. atual. e ampl., Rio de Janeiro, Forense, 2011.

CASTRO NUNES, José de. Teoria e prática do poder judiciário, Rio de Janeiro, Forense, 1943.

CAVALCANTI, Marcos. Incidente de resolução de demandas repetitivas e ações coletivas, Salvador, Juspodivm, 2015. 
CHEIM JORGE, Flávio. Apelação cível: teoria geral e admissibilidade. 1. ed, 2. tir., São Paulo, Revista dos Tribunais, 1999.

COLEMAN JR., William T. The Supreme Court of the United States: managing its caseload to achieve its constitutional purposes. in Fordham Law Review, Oct. 1983.

CRAMER, Ronaldo. Precedentes judiciais: teoria e dinâmica, Rio de Janeiro, Forense, 2016.

DANTAS, Bruno. Teoria dos recursos repetitivos: tutela pluri-individual nos recursos dirigidos ao STF e ao STJ (arts. 543-B e 543-C do CPC), São Paulo, Revista dos Tribunais, 2015.

DINAMARCO, Cândido Rangel. A instrumentalidade do processo, 14. ed., rev. e atualiz., São Paulo, Malheiros, 2009.

. Capítulos de sentença, São Paulo, Malheiros, 2002.

. Instituições de Direito Processual Civil, v. III, São Paulo, Malheiros, 2001.

. Vocabulário do processo civil, São Paulo, Malheiros, 2009.

. "A função das cortes supremas na América Latina", in Fundamentos do

Processo Civil moderno, II, São Paulo, Malheiros, 2010.

; LOPES, Bruno Vasconcelos Carrilho. Teoria geral do novo processo civil, São Paulo, Malheiros, 2016.

DUXBURY, Neil. The nature and autorithy of precedent, Cambridge, Cambridge University Press, 2008.

FONSECA, João Francisco Naves da. Exame dos fatos nos recursos especial e extraordinário, Dissertação de mestrado, USP, São Paulo, 2010.

FREITAS, Arystóbulo de Oliveira. "A falácia do excesso de recursos", in Revista do Advogado, ano XXXIX, v. 141 (abr/2019), São Paulo, Associação dos Advogados de São Paulo - AASP, 2019.

GAMA, Vasco de Lacerda. Conceituação do recurso extraordinário, Rio de Janeiro, Pongetti, 1937.

GRECO, Leonardo. Instituições de processo civil: recursos e processos de competência originária dos tribunais, vol. III, 1. ed., Rio de Janeiro, Forense, 2015.

GRECO FILHO, Vicente. Direito processual civil brasileiro, v. 2, 22. ed., São Paulo, Saraiva, 2013, p. 342.

GRINOVER, Ada Pellegrini. Novas tendências do direito processual civil: de acordo com a Constituição de 1988, São Paulo, Forense Universitária, 1990.

LEAL, Saul Tourinho. Controle de Constitucionalidade Moderno, 2. ed., Niterói, Impetus, 2012 . 
LEAL, Vitor Nunes. "Passado e futuro da súmula do STF", in Revista de Direito Administrativo, n. 145, Rio de Janeiro, jul-set/1981.

LEAL, Vitor Nunes. "Atualidade do Supremo Tribunal”, in Revista dos Tribunais, v. 53, n. 349, nov., 1964.

LEVIN, Mark R. Men in black: how the Supreme Court is destroying America, Washington, DC, Regnery Publishing, Inc., 2009.

LIMA, Tiago Asfor Rocha. Precedentes judiciais civis no Brasil, São Paulo, Saraiva 2013.

LINS, Artur Orlando. A primazia do julgamento de mérito no processo civil brasileiro: fundamentos, concretização e limites dogmáticos, Salvador, Juspodivm, 2019.

LUCCA, Rodrigo Ramina de. O dever de motivação das decisões judiciais: Estado de Direito, segurança jurídica e teoria dos precedentes, 3. ed. rev. e atual., Salvador, Juspodivm, 2019.

LUCON, Paulo Henrique dos Santos. "Abuso do exercício do direito de recorrer", in Aspectos polêmicos e atuais dos recursos cíveis e de outras formas de impugnação às decisões judiciais, NERY JR., Nelson; ALVIM, Teresa Arruda (coord.), São Paulo, Revista dos Tribunais, 2001.

MACÊDO, Lucas Buril de. Precedentes judiciais e o direito processual civil. 2. ed., Salvador, JusPodivm, 2017.

MANCUSO, Rodolfo de Camargo. Recurso extraordinário e recurso especial. 13. ed., rev., atualiz. e ampl. São Paulo, Revista dos Tribunais, 2015.

. Divergência jurisprudencial e súmula vinculante, 2. ed., São Paulo, Revista dos Tribunais, 2001.

MARINONI, Luiz Guilherme. Precedentes obrigatórios, 6. ed., rev., atual. e ampl., São Paulo, Revista dos Tribunais, 2019.

. Incidente de resolução de demandas repetitivas: decisão de questão idêntica x precedente, São Paulo, Revista dos Tribunais, 2016.

. A ética dos precedentes. $2^{\mathrm{a}}$ ed., São Paulo, Revista dos Tribunais, 2016.

; MITIDIERO, Daniel. Recurso extraordinário e recurso especial: do jus litigatoris ao jus constitutionis, São Paulo, Revista dos Tribunais, 2019.

; ARENHART, Sérgio Cruz; MITIDIERO Daniel. O novo processo civil, $2^{\text {a }}$ ed., São Paulo, Revista dos Tribunais, 2016.

MATTEI, Ugo. "Precedente giudiziario e stare decisis", in Digesto Discipline Privatistiche, v. XIV.

MEDINA, José Miguel Garcia. Prequestionamento, repercussão geral da questão constitucional, relevância da questão federal: admissibilidade, processamento e julgamento dos recursos extraordinário e especial, $7^{\mathrm{a}}$ ed. rev., ampl. e atual., São Paulo, RT, 2017. 
MEDINA, Paulo Roberto Gouvêa, "A uniformização da jurisprudência no contexto da reforma do CPC", in TEIXEIRA, Sálvio de Figueiredo (coord.), Reforma do Código de Processo Civil, São Paulo, Saraiva, 1996.

MENDES, Aluisio Gonçalves de Castro. Ações coletivas e meios de resolução coletiva de conflitos no direito comparado e nacional, 3. ed., São Paulo, Revista dos Tribunais, 2012.

MENDES, Gilmar Ferreira, Jurisdição constitucional: o controle abstrato de normas no Brasil e na Alemanha, 5. ed., São Paulo, Saraiva, 2005.

MIRANDA DE OLIVEIRA, Pedro, Recurso extraordinário e o requisito da repercussão geral, São Paulo, Revista dos Tribunais, 2013.

MITIDIERO, Daniel. Cortes Superiores e Cortes Supremas: do controle à interpretação, da jurisprudência ao precedente, 3. ed. rev., atual. e ampl., São Paulo, Revista dos Tribunais, 2017.

. Precedentes: da persuasão à vinculação. 3. ed. rev., atual. e ampl., São Paulo, Revista dos Tribunais, 2018.

NAGAREDA, Richard A. The law of Class Actions and other aggregate litigation, Foundation Press, New York, 2009.

NERY JÚNIOR, Nelson. Teoria geral dos recursos, 7. ed., rev. e atual., São Paulo, Revista dos Tribunais, 2014.

NEVES, Antonio Castanheira. "A distinção entre a questão-de-facto e a questão-de-direito e a competência do Supremo Tribunal de Justiça como tribunal de revista", in: Digesta, vol. 1, Escritos acerca do direito, do pensamento jurídico, da sua metodologia e outros, Coimbra, 2011.

OLIVEIRA, André Macedo. Recursos especiais repetitivos, Brasília, Gazeta Jurídica, 2015.

OLIVEIRA E CRUZ, João Claudino de. Dos recursos no Código de Processo Civil, n. 297, 3. ed., Rio de Janeiro, Forense, 1968.

PEIXOTO, Ravi. Superação do precedente e segurança jurídica, 4. ed., rev., ampl. e atualiz., Salvador, Juspodivm, 2019.

PEREIRA, Paula Pessoa. Legitimidade dos precedentes - universalidade das decisões do STJ. São Paulo, Revista dos Tribunais, 2014.

PINTO, Nelson Luiz, Recurso especial para o STJ, 2. ed., São Paulo, Malheiros, 1996.

REALE, Miguel. Lições Preliminares de Direito (1973), 27. ed., São Paulo, Saraiva, 2014.

RICCI, Gian Franco. Il giudizio civile di cassazione, Torino, G. Giappichelli, 2013.

RODRIGUES, Luiza Silva. Embargos de Divergência no CPC/2015, Salvador, Juspodivm, 2018. 
RODRIGUES, Marcelo Abelha. "Sistema de precedentes ou meros filtros redutores de demandas repetitivas? Angústias e desconfianças", in Revista de Processo, ano 41, n. 259 (set/2016), São Paulo, Revista dos Tribunais, 2016.

RODRIGUES, Roberto de Aragão Ribeiro, Ações repetitivas: o novo perfil da tutela dos direitos individuais homogêneos, Curitiba, Juruá, 2013.

ROSAS, Roberto. “O tribunal nacional”, in STJ 10 anos: obra comemorativa 1989-1999, Brasília, Superior Tribunal de Justiça, 1999.

ROSSI, Júlio César. Precedente à brasileira: a jurisprudência vinculante no CPC e no novo CPC, São Paulo, Atlas, 2015.

SICA, Heitor Vitor Mendonça. O direito de defesa no processo civil brasileiro, São Paulo, Atlas, 2011.

. "Congestionamento viário e congestionamento judiciário", in https://www.academia.edu/12883899/2015 Congestionamento vi\%C3\%A1rio e cong estionamento judici\%C3\%A1rio, acesso em 09.08.2019.

SOARES, Guido Fernando Silva. Common law - Introdução ao Direito dos EUA, $1^{\text {a }}$ ed., São Paulo, Revista dos Tribunais, 1999

SOUZA, Bernardo Pimentel. Introdução aos Recursos Cíveis e à Ação Rescisória, 6. ed., São Paulo, Saraiva, 2009.

STRECK, Lenio Luiz. Precedentes judiciais e hermenêutica, 2. ed., Salvador, Juspodivm, 2019.

SUNSTEIN, Cass R. One case at a time, Cambridge, Massachusetts, Harvard University Press, 1999.

TALAMINI, Eduardo. "A dimensão coletiva dos direitos individuais homogêneos: ações coletivas e os mecanismos previstos no Código de Processo Civil de 2015", in DIDIER JR., Fredie; CUNHA, Leonardo Carneiro da (coord.), Julgamento de casos repetitivos, Salvador, Juspodivm, 2017.

TARUFFO, Michele. Processo civil comparado: ensaios, trad. Daniel Mitidiero, São Paulo, Marcial Pons, 2013.

. "Precedente e jurisprudência", in Revista de Processo, n. 199, Set/2011, São Paulo, Revista dos Tribunais, 2011.

1991.

. Il vertice ambiguo - saggi sulla cassazione civile, Bolonha, Il Mulino,

TUCCI, José Rogério Cruz e. Procedimento Comum: disposições gerais até da audiência de instrução e julgamento, in Comentários ao Código de Processo Civil, vol. VII, São Paulo, Saraiva, 2016.

UZEDA, Carolina. Interesse recursal, Salvador, Juspodivm, 2018. 
VASCONCELLOS, Arnaldo. "Sobre a jurisprudência", in Revista da Faculdade de Direito da Universidade Federal do Ceará, jul-dez/1988.

VELLOSO, Carlos Mário da Silva. "Poder Judiciário: reforma. A Emenda Constitucional n. 45, de 08/12/2004”, in Revista Forense, Rio de Janeiro, Forense, v. 378, pp. 11-26, março$\mathrm{abril} / 2005$.

VIANA, Ulisses Schwarz. Repercussão geral sob a ótica dos sistemas de Niklas Luhmann, São Paulo, Saraiva, 2010.

VIGLIAR, José Marcelo Menezes. "Alguns aspectos sobre a ineficiência do procedimento especial destinado aos interesses individuais homogêneos", in MILARE, Édis (coord.), $A$ ação civil pública após 20 anos: efetividade e desafios, São Paulo, Revista dos Tribunais, 2005.

WAMBIER, Luiz Rodrigues; TALAMINI, Eduardo. Curso Avançado de Processo Civil, vol. I. 10. ed., São Paulo, Revista dos Tribunais, 2010.

; VANCONCELOS, Rita de Cássia Corrêa. "Recursos especiais repetitivos: reflexos das novas regras (Lei 11.672/2008 e Resolução 8 do STJ) nos processos coletivos", in Revista de Processo, ano 33, n. 163 (set/2008), São Paulo, Revista dos Tribunais, 2008.

ZAVASCKI, Teori Albino. Defesa de direitos coletivos e defesa coletiva de direitos, in (ZAVASCKI, Teori Albino. Defesa de direitos coletivos e defesa coletiva de direitos, in http://www2.senado.leg.br/bdsf/handle/id/176342, acesso em 01/10/2019. 